\title{
A NOVEL VACCINE CANDIDATE WITH DOUBLE ANTIVIRAL ACTIVITY AGAINST THE HIV-1 AND COVID-19
}

"CRUZ-RODRIGUEZ L. ${ }^{(1,2,3)}$, ZAYAS TAMAYO AM. ${ }^{(4)}$, SANCHEZ BATISTA L. ${ }^{(4)}$, LAMBERT BROWN D。 ${ }^{(5)}$, HOCHWIMIMER B ${ }^{(6)}$ and ZIARATI P.(7)

${ }^{1 *}$ CEO, ELIDAN Dynamic LLC, 1602 Windermere Way, Tampa, FL,33619, USA.

${ }^{2}$ CEO, ELIDAN genome SAS, 1 avenue du Lycée, 77130 Montereau Fault Yonne; France.

${ }^{3}$ ExCELab Co. Ltd., Manager Director of Environmental Biotechnology Department., Jamaica.

"Correspondence author

\author{
Dr. CRUZ-RODRIGUEZ Luis \\ CEO, \\ ELIDAN Dynamic LLC \\ 1602 Windermere Way \\ Tampa, FL, 33619,USA \\ E-mails : ceo@elidan-genome.com ; \\ luis.cruzrguez@gmail.com
}

${ }^{5}$ CEO, Family Physician, FCMC \& ExCELab Co. Ltd, Jamaica.

${ }^{6}$ CEO, Hochwimmer B. \& Asso. Pty Ltd, Albury, NSW, Australia.

Submitted : 15 April 2020 ; Published : 4 May 2020

${ }^{7}$ Nutrition and Food Sciences Research Center, Tehran Medical Sciences, Islamic Azad University, Tehran, Iran.

\begin{abstract}
Human Immunodeficiency Virus (HIV) is an RNA retrovirus with great capacity for replication and mutation. It belongs to lentiviruses, which are characterized in that the interval between the initial infection and the beginning of the main symptoms is classified into two types: HIV-1 and HIV-2, which have 40-50\% genetic homology and organization and similar genomics. HIV-1 is the cause of the global Acquired Immune Deficiency Syndrome (AIDS) pandemic while HIV-2, although it can also cause AIDS, is considered less pathogenic and less transmissible. Another differential characteristic of HIV-1 is its great genetic variability, which is contributing to making it difficult to understand the mechanisms by which the virus is capable of causing the acquired immune deficiency syndrome and which necessarily influences the development of diagnostic tests and its possibilities of prevention, the development of effective treatments and vaccines, or the appearance of resistance. We have designed a preventive vaccine in Silico aimed to protect against VIH-1 infection and transmission. One aim of this is to better understand potential dormant repositories of outbreaks and potential spread of those repositories, together with potential geogenic terrain factors. Here, we present miRNA-peptide fusion more stable as an antiviral. Our analysis identified a miRNA-peptide with theoretical fusion value stability FS=80.75 Cruz, to treat HIV-1, named LCR 2020 B0119. The vaccine candidate presents in Silico an inhibiting action against HIV-1 and coronavirus (covid-19), making its use possible as a new double-action antiviral vaccine: anti-HIV-1 and anti-covid-19.
\end{abstract}

Keywords: HIV, RNA Retrovirus, HIV-1, Covid-19, Pandemic, miRNA-peptide, Fusion Value Stability (FS), Double-Action Antiviral, Double Antiviral, Vaccine, LCR 2020 B0119.

\section{Introduction}

For many years the World Health Organization (WHO) has developed a Special Program on Human Immunodeficiency Virus (HIV to reduce the disease, and several countries have made progress towards eliminating mother-to-child transmission, as well as engaging in different virus response initiatives included in brother health and development programs [1].
HIV is an RNA retrovirus with great capacity for replication and mutation. It belongs to lentiviruses, which are characterized in that the interval between the initial infection and the beginning of the main symptoms is classified into two types: HIV-1 and HIV-2, which have 40-50\% genetic homology and organization and similar genomics. HIV-1 is the cause of the global AIDS pandemic while HIV-2, although it can also cause AIDS, is considered less pathogenic and less transmissible [2]. 
Another differential characteristic of HIV-1 is its great genetic variability, which is contributing to making it difficult to understand the mechanisms by which the virus is capable of causing the acquired immune deficiency syndrome and which necessarily influences the development of diagnostic tests and its possibilities of prevention, the development of effective treatments and vaccines, or the appearance of resistance [3].

The latency of the human immunodeficiency virus (HIV-1) is clinically highlighted through the persistence of a residual viral load in treated patients due to the reactivation of cellular reservoirs. Through effective antiretroviral therapy it generally leads to undetectable HIV-1 RNA in the plasma. However, the virus persists in some cells of infected patients as various forms of DNA, both integrated and non-integrated. [4,5].

HIV, like any other retrovirus, has a single-stranded RNA (ss) genome that depends on a single enzyme, retrotrancriptase, to convert its genomic RNA into DNA (provirus) that is later integrated into the cellular genome $[6,7]$.

According to the WHO, viral diseases continue to emerge episodically and represent a serious issue to public health. In the last twenty years, several viral epidemics such as the severe acute respiratory syndrome coronavirus (SARS-CoV from 2002 to 2003, and H1N1 influenza in 2009, have been recorded). In December 2019, a cluster of patients with pneumonia of unknown cause was linked to a seafood wholesale market in Wuhan, China. A previously unknown betacoronavirus was identified through the use of unbiased sequencing in samples from patients with pneumonia.

On January 10, 2020, the first 2019-ncov genome was sequenced, followed by five subsequent viral genome sequences [9]. The new coronavirus, formed a clade within the subgenus Orthocoronavirinae, sarbecovirus subfamily. The first time these cases were published they were classified as "pneumonia of unknown etiology." The Chinese Center for Disease Control and Prevention (CDC) and local CDCs organized an intensive outbreak investigation program. The etiology of this illness is now attributed to a novel virus belonging to the coronavirus (CoV) family, COVID-19. Different from both MERS-CoV and SARS-CoV, 2019-nCoV it is the seventh member of the family of coronaviruses to infect humans [10]. The clinical range of the disease, new diagnostics, prevention and treatment strategies are in process of development [11].

Unfortunately, insufficient research leading up to purported species-species viral transmission is alarming. We know they are more frequently episodic, yet always assume a systemic closed biology. This may be a faulty discipline assumption since the increasing episodic nature of viral transmission bears scrutiny on potential physiographic-climactic links. These in turn are open to geogenic-geological connections with terrain biology and ecology. The whole biological cycle of the virus and host and the evolution of the epidemic, especially when the epidemic will reach its peak is unknown. Terrain-controlled genomic studies in soil geo-microbiology and invertebrate
Medical Geology to higher species-species transmissions studies are recommended. This may extend the viral genomic phylogenic trees beyond the species-species barriers and diversity of potential future impacts. Geologists do not consider the possibility of spreading the disease by air, water, and earth. The discipline of Medical Geology can translate this enigmatic situation using its potential to understand the planet and human health relationships $[12,13,14]$.

One aim of this is to better understand potential dormant repositories of outbreaks and potential spread of those repositories, together with potential geogenic terrain factors and triggers. Integrated research in vaccine testing with such 'wild type' genomic diversity research is recommended to be also open to viral Medical Geology studies, as a new discipline $[15,16]$.

A better wild-type viral genomics understanding leading up to the current pandemics of HIV-1 and covid-19 is needed along with research into potential dormant repositories of outbreaks and the spread of those repositories, geogenic terrain factors and triggers. This will help understand the episodic, recurring and frequent nature of outbreaks and potential virulent and contagious future outbreaks. Quantification of HIV-1/covid-19 DNA in blood samples is currently the most practical approach to measure this residual infection. Quantitative real-time PCR (qPCR) is the most common method used to quantify HIV1/covid-19 DNA, and many strategies have been developed to measure the different forms of HIV-1 DNA. Various "internal" PCR methods have been used in the literature and standardization needs to have comparable results. Since the development of an HIV-1/covid-19 vaccine has not been accomplished and therefore remains a major challenge for immunologists, the future direction towards effective curative therapy for HIV-1/covid-19 infection will depend on the development of strategies and original therapeutics that consider latency, chronic replication and accessibility to the tissue sanctuary $[4,5]$.

Here we have identified a miRNA-peptide fusion: LCR_2020_ B0119 with fusion value stability $\mathrm{FS}=80.75 \mathrm{Cruz}$, as the vaccine candidate that we propose to integrate in the research in vaccine testing with 'wild type' genomic phylogenic evolution studies as part of viral Medical Geology studies utilizing a small part of the viral vaccine funding recommended. One aim of this is to better understand potential dormant repositories of outbreaks and potential spread of those repositories, together with potential geogenic terrain factors and triggers $[16,17,18]$.

\section{Materials and Methods}

Homology modelling has evolved into an important procedure in structural biology, significantly contributing to narrowing the gap between known protein sequences from a virus HIV-1 isolate BEC55 from USA nef protein (nef) gene and designed protein in silico structures.

The antiviral proteins were designed as protein inhibitors using 
PARP-1 peptide in the fusion. The inhibition was due to protein-protein interactions. A cleavage site has been adjusted (DEVD) in the peptide to induce the caspases 3 and 7 action, and thereby apoptosis in infected cells, while on the other hand, in cells not infected apoptosis is not induced, and the synthesis of the miRNA will allow an antigen involved in production of antibodies against the HIV-1 and covid-19. The miRNA 3' and peptide N-terminus will both be modified for click chemistry conjugation [19]. (Figure 1 below)

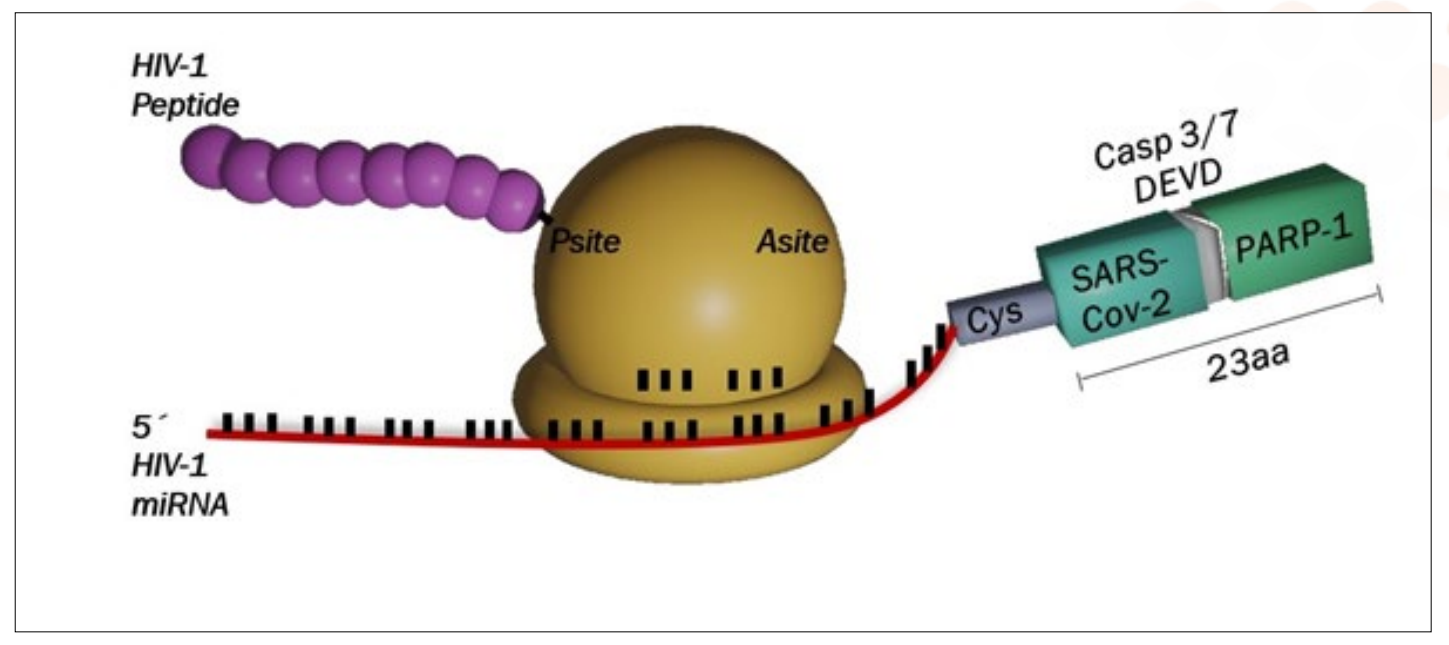

Figure 1 indicates fusion stability (FS) between primers of miRNA of HIV-1 and peptide (spacing arm (Poly Cys) and fused molecules SARS-CoV-2 and PARP-1).

Gene targets:

Ontology enrichment analysis:

The primers used as miRNA target are represented in five different colors in the sequencing below.

$>$ GU046585.1 HIV-1 isolate BEC55 from USA nef protein (nef) gene, complete cds

5`ATGGGTGGCAAATGGTCAAAATGTAGTGTA GTTGGATGGCCTGCTGTAAGGGAAAGAATGAAACGA GCTGAGCCAGCAGCAGATGGGGTGG GAGCAGTATCTCGAGACCTGG AAAAACATGGAGCAATCACAAG

TAGCAATACAGTAGATACTAATGCTGCTTGTG CCTGGCTGGAAGCACAAGA GGAGGAGGAGGTGGGTT

TTCCAGTCAGACCTCAGGTACCTTT AAGACCAATGACTTATAAGGGAGCTCTAGAT

CTTAGCCACTTCTTAAAAGAAAAGGGGGGA CTGGAAGGGCTAATTTTCTCCC

AAAGAAGACAAGATATCCTTGATCTGTGG GTCTACAACACACAAGGTTACTTCCCTGATTGG

CAGAACTACACGCCAGGGCCAGGGATTAGATATCC ACTGACCTTTGGATGGTGCTTCAAGCTAGTACCAGTT

GAGCCAGAGAAGGTAGAAGAAGCCAATGAAG GAGAGAACAACAGCTTGTT ACACCCTATGAGCCAGCATGG

AATAGATGACCCGGAGAGAGAAGTGTT AGCGTGGAGGTTT GACAGCCGCCTAGCATTCCATCACAT

GGCCCGAGAGCTGCATCCGGAGTACTAC AAAAACTGCTGA3`

\begin{tabular}{|l|l|l|l|}
\hline Code & cDNA $\left(5^{\prime}-3^{\prime}\right)$ & miRNA $\left(5^{\prime}{ }^{\prime} 3^{\prime}\right)$ & Size $\left(\mathrm{nt}^{\prime}\right)$ \\
\hline $\mathrm{a}$ & $\begin{array}{l}\text { CTTAGCCACTTCTTAAAA } \\
\text { GAAAAGGGGGGA }\end{array}$ & $\begin{array}{l}\text { CUUAGCCACUUCUUAAAA } \\
\text { GAAAAGGGGGGA }\end{array}$ & 30 \\
\hline $\mathrm{b}$ & $\begin{array}{l}\text { ATGGGTGGC } \\
\text { AAATGGTCAAAATGTA } \\
\text { GTGTA }\end{array}$ & $\begin{array}{l}\text { AUGGGUGGCAAA } \\
\text { UGGUCAAAAUGUAGUGUA }\end{array}$ & 30 \\
\hline $\mathrm{c}$ & $\begin{array}{l}\text { AAAAACATGG } \\
\text { AGCAATCACAA }\end{array}$ & AAAAACAUGG AGCAAUCACAA & 21 \\
\hline $\mathrm{d}$ & $\begin{array}{l}\text { AATAGATGA } \\
\text { CCCGGAGAGAGAA GTGTT }\end{array}$ & $\begin{array}{l}\text { AAUAGAUGA } \\
\text { CCCGGAGAGAGAAGUGUU }\end{array}$ & 27 \\
\hline $\mathrm{e}$ & AAAAACTGCTGA & AAAAACUGCUGA & 12 \\
\hline
\end{tabular}

Table 1 shows in five different colors the codes assigned to the primers of cDNA and miRNA. The five sequences of miRNA were utilized in the design of the vaccine against VHI-1 and covid-19.

All primers were validated for their stability after peptide fusion. Statistical analysis [20 ].

I J Infectious Disea; $2020 \quad$ www.unisciencepub.com 


\begin{tabular}{|c|c|c|}
\hline miRNA & Poly (A )+ PRIMER & Poly Cys + PEPTIDE \\
\hline $\mathrm{a}$ & $\begin{array}{l}\text { 5`AAAAAAAAAA-- } \\
\text { CUUAGCCACUUCUU } \\
\text { AAAAGAAAAGGGGGGA }\end{array}$ & $\begin{array}{l}\text {-CCCCC- } \text { (spacing arm) } \\
\text { VNCDTFCAGSTFISDEVDGVDEVAKKKSK }\end{array}$ \\
\hline $\mathrm{b}$ & $\begin{array}{l}\text { 5`AAAAAAAAAA-- } \\
\text { AUGGGUGGCAAAUGG } \\
\text { UCAAAAUGUAGUGUA }\end{array}$ & $\begin{array}{l}-C C C C C-\text { (spacing arm) } \\
\text { VNCDTFCAGSTFISDEVDGVDEVAKKKSK }\end{array}$ \\
\hline $\mathrm{c}$ & $\begin{array}{l}\text { 5`AAAAAAAAAA-- } \\
\text { AAAAACAUGGAGCAAUCACAA }\end{array}$ & $\begin{array}{l}- \text {-CCCCC- } \text { - (spacing arm) } \\
\text { VNCDTFCAGSTFISDEVDGVDEVAKKKSK }\end{array}$ \\
\hline d & $\begin{array}{l}\text { 5`AAAAAAAAAA-- } \\
\text { AAUAGAUGACCCGGA } \\
\text { GAGAGAAGUGUU }\end{array}$ & $\begin{array}{l}\text {-CCCCC- } \text { (spacing arm) } \\
\text { VNCDTFCAGSTFISDEVDGVDEVAKKKSK }\end{array}$ \\
\hline $\mathrm{e}$ & $\begin{array}{l}\text { 5`AAAAAAAAAA-- } \\
\text { AAAAACUGCUGA }\end{array}$ & $\begin{array}{l}\text {-CCCCC---(spacing arm) } \\
\text { VNCDTFCAGSTFISDEVDGVDEVAKKKSK }\end{array}$ \\
\hline
\end{tabular}

Tabla 2 shows the five primers of miRNA utilized as candidates for fusion with the peptide selected for the vaccine against VHI-1 and Covid-19. In this table the number of nitrogenous bases and the size of primer can be observed. Polyadenylation (number of Adenines adjusted to the top $5{ }^{`}$ of the primer and the number of Cys adjusted to the peptide used as spacing arm between miRNA and peptide).

The peptide utilized has been the following:

I. Full peptide sequencing (34 amino acids included spacing arm + peptide)

\section{---CCCCC---VNCDTFCAGSTFISDEVDGVDEVAKKKSK}

\section{After cleavage of caspase 3/7}

I.1 https://blast.ncbi.nlm.nih.gov/Blast.cgi\#alnHdr_ QHW06038

ORF1AB POLYPROTEIN [SEVERE ACUTE

RESPIRATORY SYNDROME CORONAVIRUS 2]

\section{I.1.1 Peptide which corresponds to Avian Coronavirus}

\section{---CCCCC---VNCDTFCAGSTFISDEVD}

I.2 https://blast.ncbi.nlm.nih.gov/Blast.cgi\#alnHdr_ AAL02174

HUMAN PARP-1 (11 amino acids) Poly(ADP-ribose) polymerase, partial [Homo sapiens]

\section{GVDEVAKKKSK}

The mathematical formula utilized for estimating the stability of the fusion between DNA and the selected peptide is:

$$
\begin{aligned}
& \quad F S_{=a b c d, \text { where: }} \\
& a=\frac{S_{\text {Poly } A}}{S_{\text {Poly } C y s}}, \quad b=\frac{M W_{\text {miRNA }}}{M W_{\text {Peptide }}}, \quad c=\frac{S_{\text {Peptide }}}{S_{\text {miRNA }}}, \\
& d=\frac{[2(A+\beta)+3(C+G)]}{X\left(p I_{1}, p I_{2}, \ldots, p I_{n}\right)},
\end{aligned}
$$

$$
\begin{array}{ll}
S_{\text {Poly A }} & : \text { Poly (A) size } \\
S_{\text {PolyCys }} & : \text { Poly Cys size } \\
M W_{\text {miRNA }} & : \text { miRNA Molecular Weight } \\
M W_{\text {Peptide }} & : \text { Peptide Molecular Weight } \\
S_{\text {Peptide }} & : \text { Peptide size [aa] } \\
S_{\text {miRNA }} & : \text { miRNA Size }
\end{array}
$$

$\beta=\mathrm{T}$ if DNA or $\beta=\mathrm{U}$ if RNA

pI: point Isoelectric

n: peptide size

This formula has been developed by Dr. Luis CRUZRODRIGUEZ and named Fusion Stability Curve (FS): CRUZRODRIGUEZ. Its unit of measurement has been named "Cruz". The ideal value for reference of FS is 100 Cruz, such that a result of $\mathrm{FS}=64.28 \mathrm{Cruz}$ is equivalent to a value of $64.28 \%$ with respect to the ideal fusion between a DNA or RNA primer and a peptide, as is the case in the fusion performed for the study of candidate vaccines against covid-19 [21].

\section{Results and Discussion}

\section{Bioinformatics identification of miRNAs}

Prior to analysis, readings containing poly-N, with 5' Cys peptide fusion with a 3 ' insert tag, containing PolyA (10 nt of Alanine to all primers were added). The small miRNA was clustered with a PARP-1 peptide with caspase site DEVD, and the percentage of differential of Fusion Stability (FS) RNApeptide was calculated in "Cruz". The mapped small miRNA 
readings were examined for the presence of known miRNAs using MiRBase20.0 (http://www.mirba se.org/). Based on this analysis five vaccine candidates were identified (Figure 2 below).

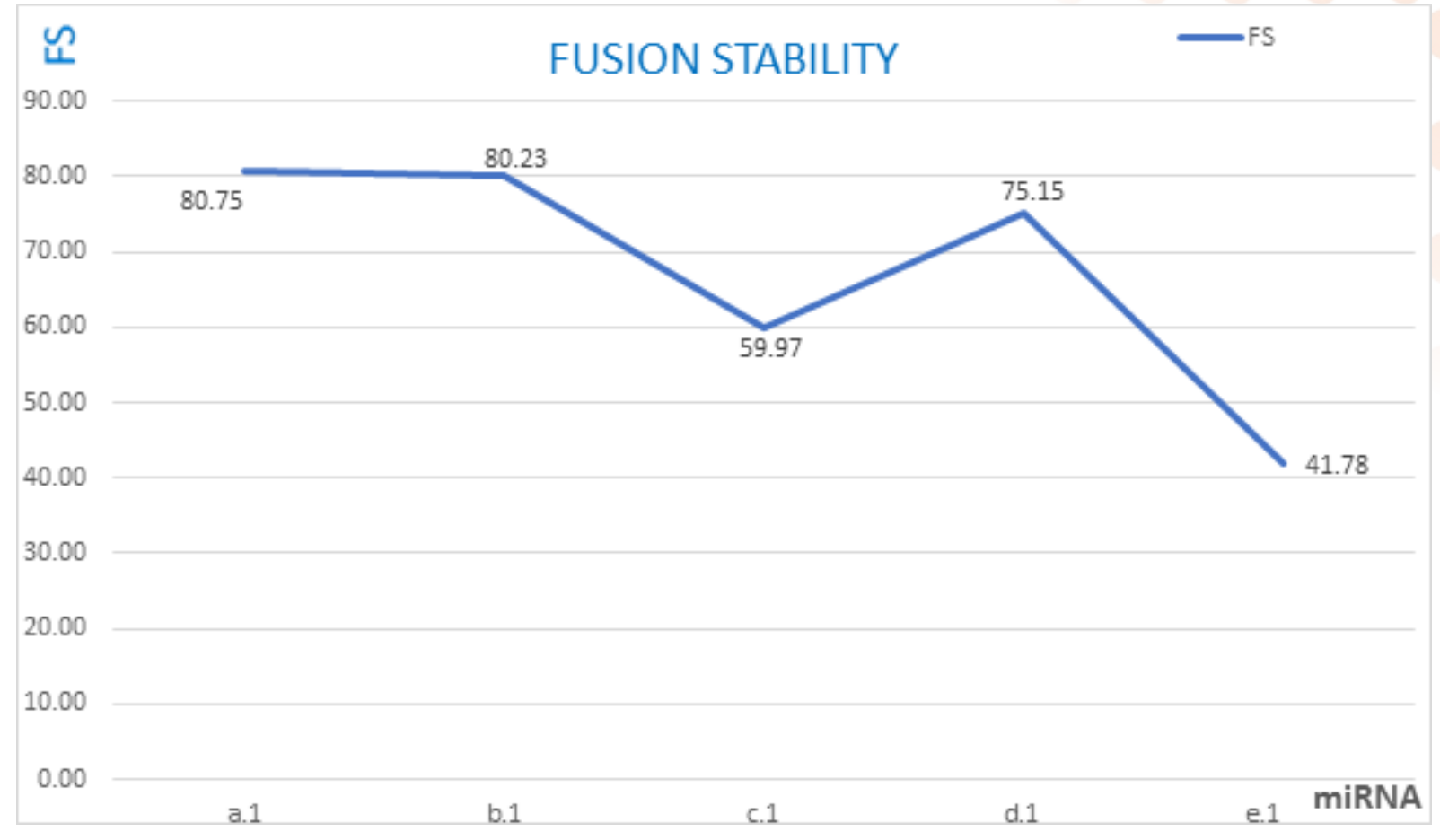

Figure 2 shows the stability value of the fusion between the different miRNAs (a,b,c,d,e). The selected fusion is: (a.) 5'AAAAAAAAAA----CTCCTAGAACTAGCATTACAGATG----

CCCCCVNCDTFCAGSTFISDEVDGVDEVAKKKSK has FS $=80.75$ Cruz

The most representative fusion stability was 80.75 Cruz and was named: ANTIVIRAL CHEMICAL CHIMERA FORMULA "LCR 2020 B0119": Antiviral chemical chimera formula: against Human Immunodeficient Virus “type-1” Virus (HIV-1) and Human coronavirus (covid-19).

The miRNA-peptide fusion (a.) was identified as the highest value $\mathrm{FS}=80.75 \mathrm{Cruz}$, as the vaccine candidate that we propose to integrate into research in vaccine tests with genomic phylogen of 'wild type' evolution studies as part of viral medical geology studies using a small part of the recommended vaccine funding.

\section{Conclusions and Perspectives}

Our analysis in Silico identified a stable fusion miRNApeptide from 5 vaccine candidates aimed to prevent HIV-1 and covid-19 infections [23].

The vaccine candidate with the highest FS was named: LCR_2020_B0119: Patent Rights: 2004153662342

It presents a cleavage site for enzymes Caspase-3 and Caspase-7 which are both activated universally during apoptosis, irrespective of the specific death-initiating stimulus, and both proteases are widely considered to coordinate the demolition phase of apoptosis by cleaving as a protein substrate. Inoculation is expected to be orally with appropriate doses.

The vaccine candidate LCR_2020_B0119 presents in Silico an antiviral action against HIV-1 and the coronavirus covid-19, making it possible to be used as a double action vaccine: antiHIV-1 and covid-19.

\section{ACIKNOWLEDGMENTS}

Thanks to:

\section{Mr. Oslay CRUZ-RODRIGUEZ \\ Mr. Eduardo Jesús MARRERO-RODRIGUEZ \\ Ms. Estrella Marina RODRIGUEZ VALLADARES}

\section{Reference}

1. WHO/HIV/2016.05. www.who.int/hiv

2. Delgado R (2011) "Virological characteristics of HIV1 ". Infectious Diseases and Clinical Microbiology 29(1): 58-65.

3. Cherrier T, Le Douce V, Redel L, Marban C, Aunis D, Rohr O, Schwartz C (2010) "Molecular basis of HIV-1 latency Part II: HIV-1 reactivation and therapeutic implications". Med Sci (Paris). 2010 Mar;26(3): 291-295. doi: 10.1051/ medsci/2010263291

4. Bouchat S, Van Lint C (2019) "Viral latency of HIV-1"; Virologie (Montrouge) 23(4): 195-210. doi: 10.1684/ vir.2019.0782. 
5. Figiel M, Krepl M, Park S, Poznański J, Skowronek K, Gołąb A, Ha T, Šponer J, Nowotny M (2018) "Mechanism of polypurine tract primer generation by HIV-1 reverse transcriptase". J Biol Chem 293(1): 191-202. doi: 10.1074/ jbc.M117.798256. Epub 2017 Nov 9.

6. Alidjinou EK, Bocket L, Hober D (2015) “Quantification of viral DNA during HIV-1 infection: A review of relevant clinical uses and laboratory methods". Pathol Biol (Paris) 63(1): 53-59. doi: 10.1016/j.patbio.2014.07.007. Epub 2014 Sep 8.

7. Wang Z (2020) "A Handbook of 2019-nCoV Pneumonia Control and Prevention", Hubei Science and Technology Press. January 2020.

8. Cascella M, Rajnik M, Cuomo A, Dulebohn SC, Di Napoli R (2020) "Features, Evaluation and Treatment Coronavirus (COVID-19)", SourceStatPearls. Treasure Island (FL): StatPearls Publishing; 2020-Mar 8.

9. Alidjinou EK, Bocket L, Hober D (2015) "Quantification of viral DNA during HIV-1 infection: A review of relevant clinical uses and laboratory methods". Pathol Biol (Paris) 63(1): 53-59. doi: 10.1016/j.patbio.2014.07.007. Epub 2014 Sep 8

10. Centeno JA, Finkelman RB, Selinus O (2016) "Medical Geology: Impacts of the Natural. Environment on Public Health": Geosciences 6: 8. doi:10.3390/geosciences 6010008

11. Selinus, O, Finkelman, B, Centeno, JA, 2009. Editors (2010) "Medical Geology - a regional synthesis". Springer. 2010.

12. Selinus O, Alloway B, Centeno JA, Finkelman RB, Fuge R, Lindh U, Smedley, P (2005) "Essentials of Medical Geology"; 2005 Elsevier, Amsterdam, 820 p. (second edition published by Springer 2012).

13. Hochwimmer B. and Cruz-Rodriguez L (2005) "The Polygonal Vortex Mineralisation Model: a predictive tool of health indices and the proposed use of such "geologically based public health indices as a sub discipline of Medical Geology". 2005, ISBN 9697117037.

14. Cruz-Rodriguez L, Hochwimmer B., Selinus O (2005) "Medical Geology in Cuba". 2005, ISBN 9697117037.

15. Hochwimmer B, Ziarati P, Selinus O, Elwej A, CruzRodriguez LD, Lambert Brown D, Zayas Tamayo AM, Moradi M, Cruz-Rodriguez L (2020) “A Predictive Geological Tool of Type 3 Diabetes (Alzheimer's Disease): The Polygonal Vortex Mineralisation Model a Medical Geology Perspective“ Journal of Diabetes and Endocrinology Research: https://unisciencepub.com/wpcontent/uploads/2020/04/A-Predictive-Geological-Toolof-Type-3-Diabetes-The-Polygonal-Vor.pdf

16. Cruz-Rodriguez L, Lambert Brown D, Hochwimmer B, Selinus O, Cruz-Rodriguez LD, Cruz-Rodriguez ME, Zayas Tamayo AM, Sanchez Batista L (2020) "A miRNApeptide fusion as a vaccine candidate against the novel coronavirus (covid-19)",2020b, Journal of Diabetes and Endocrinology Research; https:/unisciencepub.com/wpcontent/uploads/2020/04/A-miRNA-PEPTIDE-FUSIONAS-A-VACCINE-CANDIDATE-AGAINST-THENOVEL-CORONAVIRUS-COVID-19.pdf
17. Waterhouse A, Bertoni M, Bienert S, Studer G, Tauriello G, Gumienny R, Heer FT, de Beer TAP, Rempfer C, Bordoli L, Lepore R, Schwede T (2018) "SWISSMODEL: homology modelling of protein structures and complexes", Nucleic Acids Res 46(W1): W296-W303. doi: 10.1093/nar/gky427.

18. Kemp V, Laconi A, Cocciolo G, Berends AJ, Breit T, Verheije MH (2020) " miRNA repertoire and host immune factor regulation upon avian coronavirus infection in eggs", Archives of Virology 16: 835-843. https://doi. org/10.1007/s00705-020-04527-4

19. Sun P, Lu X, Xu C, Sun W, Pan B (2020) "Understanding of COVID-19 based on current evidence", J Med Virol. 2020 Feb 25. doi: 10.1002/jmv.25722

20. Cruz-Rodriguez L, Cruz-Rodriguez LD, Sanchez Batista L, Hochwimmer B (2020) "Calculation of fusion stability of (DNA or RNA)-peptide (FS) algorithm "CRUZRODRUGUEZ": Journal of Bioscience \& Biomedical Engineering, 2020.

21. Delgado R (2011) "Virological characteristics of HIV1". Infectious Diseases and Clinical Microbiology 29(1): $58-65$.

Copyright: (C2020 CRUZ-RODRIGUEZ Luis .This is an open-access article distributed under the terms of the Creative Commons Attribution License, which permits unrestricted use, distribution, and reproduction in any medium, provided the original author and source are credited. 